\title{
Photodegradation of odorous 2-mercaptobenzoxazole through zinc oxide/hydroxyapatite nanocomposite
}

\author{
F. Buazar $\cdot$ S. Alipouryan $\cdot$ F. Kroushawi $\cdot$
}

S. A. Hossieni

Received: 20 August 2014/ Accepted: 27 September 2014/Published online: 19 October 2014

(C) The Author(s) 2014. This article is published with open access at Springerlink.com

\begin{abstract}
In this study, $\mathrm{ZnO} / \mathrm{HAP}$ nanocomposite with excellent photocatalytic activities was successfully synthesized by sol-gel method and used for degradation of 2-mercaptobenzoxazole (MBO) as model of odorous mercaptan compound in water. To optimize the performance of $\mathrm{ZnO} /$ HAP photocatalytic capabilities, ZnO/HAP loading (0.05$0.3 \mathrm{~g} / \mathrm{L})$, irradiation time (15-180 $\mathrm{min}), \mathrm{pH}(3-11)$ and initial concentration of MBO (10-100 ppm) were investigated. At neutral $\mathrm{pH}$ of 7 , the highest amount of the MBO (99.45\%) was degraded by $\mathrm{ZnO} / \mathrm{HAP}$ nanocomposite through photocatalytic oxidation process within $2 \mathrm{~h}$ of irradiation time. A maximum adsorption capacity of $197.64 \mathrm{mg} \mathrm{g}^{-1}$ was obtained for $\mathrm{ZnO} / \mathrm{HAP}$ under optimized conditions. BET
\end{abstract}

Electronic supplementary material The online version of this article (doi:10.1007/s13204-014-0368-4) contains supplementary material, which is available to authorized users.

F. Buazar $(\bowtie)$

Department of Marine Chemistry, Khoramshahr

University of Marine Science and Technology,

P.O. Box 669, Khoramshahr, Iran

e-mail: f.buazar1979@gmail.com

F. Buazar · S. Alipouryan

Nanotechnology Research Centre, Ahvaz Jundishapur University

of Medical Sciences, P.O. Box 61357-33184, Ahvaz, Iran

F. Kroushawi

Department of Energy Conversion and Storage, Technical University of Denmark, Ris $\emptyset$ Campus, Frederiksborgvej 399, Building 779, 4000 Roskilde, Denmark

F. Kroushawi

Department of Physics, Vali-e-Asr University of Rafsanjan,

P.O. Box 518, Rafsanjan, Iran

S. A. Hossieni

Nutrition and Metabolic Diseases Research Center, Ahvaz

Jundishapur University of Medical Sciences, Ahvaz, Iran results indicated that $\mathrm{ZnO} / \mathrm{HAP}$ had a surface area of $182.36 \mathrm{mg}^{2} \mathrm{~g}^{-1}$ which was much greater than pure $\mathrm{ZnO}$ nanoparticles $\left(31.2 \mathrm{mg}^{2} \mathrm{~g}^{-1}\right)$. TEM image demonstrated a spherical shape structure of $\mathrm{ZnO} / \mathrm{HAP}$ with average particle size of $25 \mathrm{~nm}$ in diameter. The XRD patterns revealed the principal components of $\mathrm{ZnO} / \mathrm{HAP}$ including $\mathrm{HAP}$ and $\mathrm{ZnO}$. FTIR spectrum results supported formation $\mathrm{ZnO}$ and HAP by their stretching mode in composite. Comparison of photocatalytic activity of $\mathrm{ZnO} / \mathrm{HAP}$ with pure $\mathrm{ZnO}$ and HAP nanoparticles had clearly recognized that latter is the most active photocatalyst in the degradation of MBO using UV light as source energy. The reason for greater activity of $\mathrm{ZnO} / \mathrm{HAP}$ was due to its larger specific surface area $\left(182.36 \mathrm{~m}^{2} \mathrm{~g}^{-1}\right)$ and high generation of active $\mathrm{HO}^{-}$and $\mathrm{O}_{2}^{-2}$ species.

Keywords Nanocomposite - 2-Mercaptobenzoxazole · $\mathrm{ZnO} / \mathrm{HAP} \cdot$ Photodegradation

\section{Introduction}

Mercaptans are unpleasant odorous organosulfur pollutants which are produced by the wood-pulping industry, manure and sewer systems as exhaust gases in natural environments (Greyson 1990; Leh and Chan 1973). Environmental Protection Agency of United States (EPA) estimates that over 450 tons of mercaptan may be lost annually into the environment with great impact on human health. So removal of organosulfur compounds from aqueous solution has been one of the major investigations in the last decades (Habibi and Sheibani 2012). Among them, the pollution of the environment by 2-mercaptobenzoxazole (MBO) is always of great concern for aquatic organisms. MBO is widely used in industries as rubber vulcanization or corrosion inhibitor (Allaouia and Wong-Wah-Chung 2010). Some studies on the

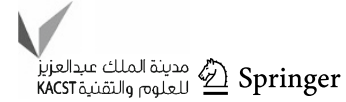


environmental behavior and the biodegradation of $\mathrm{MBO}$ indicated that in environmental conditions it is very stable and cannot completely mineralized (Allaouia and Wong-WahChung 2010; Habibi and Sheibani 2012). To the best of our knowledge, very few works were reported specifically on the removal of MBO (Antonopoulou et al. 2014; Habibi and Sheibani 2010; Parham and Khoshnam 2013). Hence, in aspect of established toxicity, low biodegradability and persistence of MBO in natural compartments, further work on its elimination and/or mineralization needs to be addressed.

$\mathrm{ZnO}$ nanoparticles (Nps) is well-known photocatalyst (Chong et al. 2010; Georgekutty et al. 2008; Hariharan 2006) for the degradation of several environmental contaminants due to its chemical inert, high photosensitivity, high electron mobility, stability, large band gap $(3.37 \mathrm{eV})$ and non-toxic properties (Bahnemann 1991; Deng et al. 2008; Yusoff et al. 2014). Likewise, $\mathrm{ZnO}$ Nps are identified as the most promising sorbent due to their high metal uptake (Ali 2012; Mahdavi et al. 2012; Mohammad Vaseem and Hahn 2010; Sheela et al. 2012). Since the photocatalytic reaction occurs on the surface of $\mathrm{ZnO} \mathrm{Nps,} \mathrm{its} \mathrm{photocatalytic} \mathrm{activity} \mathrm{can} \mathrm{increase} \mathrm{through}$ immobilization of the catalyst onto a substrate that improves its surface properties (Bai et al. 2013; Saravanan et al. 2013).

In this connection, hydroxyapatite (HAP), with nominal composition $\mathrm{Ca}_{10}\left(\mathrm{PO}_{4}\right)_{6}(\mathrm{OH})_{2}$, can be considered as valuable candidate for supporting material due to its bio-compatibility and excellent adsorption properties toward diverse water pollutants (Azzaoui et al. 2014; Hokkanen et al. 2014). Meanwhile, HAP was recognized for its high potential in trapping and retention of toxic heavy metals (Liu et al. 2013; Xie et al. 2013; Zhao et al. 2014b) and photocatalytic decomposition of toxic organic materials (Bouyarmane et al. 2013; Wei et al. 2014) in polluted water. Yet, no report has been published on removal of organic MBO pollutant from water via $\mathrm{ZnO} / \mathrm{HAP}$ nanophotocatalyst. So, following our pervious studies on synthesis of Nps (Buazar et al. 2012; Kassaee and Buazar 2009; Kassaee et al. 2008), in this paper, ZnO/HAP nanocomposite was synthesized using simple and cost-effective sol-gel procedure. The effect of parameters such as $\mathrm{ZnO} / \mathrm{HAP}$ doses, initial concentration of $\mathrm{MBO}$, irradiation time and $\mathrm{pH}$ were investigated on the photooxidation of $\mathrm{MBO}$ in water under UV irradiation. Owing to the adsorption properties of $\mathrm{HAP}$ and the photocatalytic properties of $\mathrm{ZnO}$, the results demonstrated that photodecomposition of $\mathrm{MBO}$ on $\mathrm{ZnO} / \mathrm{HAP}$ surface was much faster than pure $\mathrm{ZnO}$ and HAP Nps.

\section{Materials and methods}

Materials

Zinc acetate dihydrate $\left(\mathrm{Zn}\left(\mathrm{CH}_{3} \mathrm{COO}\right)_{2} \cdot 2 \mathrm{H}_{2} \mathrm{O}\right)$ $(99.99 \%, w / w)$, 2-propanol $\left(\mathrm{C}_{3} \mathrm{H}_{7} \mathrm{OH}\right)(99.99 \%$,w/w), pure ethanol $\left(\mathrm{CH}_{3} \mathrm{CH}_{2} \mathrm{OH}\right)$, 2-aminoethanol (MEA, $\mathrm{C}_{2} \mathrm{H}_{7} \mathrm{NO}$ ), calcium nitrate $\left(\mathrm{Ca}\left(\mathrm{NO}_{3}\right)_{2} \cdot 4 \mathrm{H}_{2} \mathrm{O}\right)$ and di-ammonium hydrogen phosphate $\left(\left(\mathrm{NH}_{4}\right)_{2} \mathrm{HPO}_{4}\right)$ were of analytical grade and purchased from Merck (Darmstadt, Germany). 2-Mercaptobenzoxazole (CAS No. 2382-96-9, Fluka, Swiss) is used as organic pollutant (Fig. 1). Deionized (DI) water is used for rinsing and for makeup of all aqueous solutions.

\section{Sol-gel synthesis of $\mathrm{ZnO} / \mathrm{HAP}$ nanocomposite}

$\mathrm{ZnO} / \mathrm{HAP}$ nanopowder was synthesized using the sol-gel technique (Hayat et al. 2011). Typically, appropriate amount of zinc acetate $(0.018 \mathrm{~mol})$ is solved in $20 \mathrm{~mL}$ of 2-propanol for $1 \mathrm{~h}$, then $20 \mathrm{~mL}$ of MEA was added to a solution of zinc acetate. Sol was stirred in hot water bath at $65{ }^{\circ} \mathrm{C}$ for $1 \mathrm{~h}$, then water was added drop-wise to the above solution under vigorous mechanical stirring $(1,400 \mathrm{rpm})$ for $10 \mathrm{~min}$. The white precipitate was produced instantly. Separately, mixture solution consisting of $0.034 \mathrm{~mol}$ $\left(\mathrm{Ca}\left(\mathrm{NO}_{3}\right)_{2} \cdot 4 \mathrm{H}_{2} \mathrm{O}\right)$ and $0.023 \mathrm{~mol}\left(\mathrm{NH}_{4}\right)_{2} \mathrm{HPO}_{4}$ with $\mathrm{pH}$ adjusted to 11 were added drop-wise to the obtained precipitate solution within $30 \mathrm{~min}$. The resulting white suspension was heated at $90{ }^{\circ} \mathrm{C}$ for $1 \mathrm{~h}$ and then the sol mixture was aged for $24 \mathrm{~h}$ without stirring. The obtained precipitate was washed several times with ID water then dried in an oven at $90^{\circ} \mathrm{C}$ for $3 \mathrm{~h}$ and finally ground with mortar.

\section{Characterization of $\mathrm{ZnO} / \mathrm{HAP}$}

The morphology and size of the synthesized ZnO/HAP nanocomposite were probed on Leo $912 \mathrm{AB}$ transition electron microscope (TEM) at an accelerating voltage of $120 \mathrm{kV}$. Infrared spectra of chemical compositions of as prepared $\mathrm{ZnO} / \mathrm{HAP}$ nanocomposite were recorded on Fourier transform infrared spectroscopy (FTIR, Brucker Tensor 27) spectrometer using a $\mathrm{KBr}$ wafer. Crystal structure and the size of nanocomposite were obtained from X-ray diffraction (XRD) on a Xpret Pro-Philips diffractometer with $\mathrm{CuK}(\lambda=1.5405 \AA)$ radiation at a scanning speed of $2 / \mathrm{min}$ from 10 to $80(2 \theta)$. The BrunauerEmmett-Teller (BET) specific surface area of the synthesized materials is determined by nitrogen adsorptiondesorption at $77.30 \mathrm{~K}$ using an ASAP2450 apparatus.

Photocatalytic experiments

The photodegradation procedure of $\mathrm{MBO}$ was conducted in a photoreactor (Fig. 2). Firstly, $25 \mathrm{~mL}$ sample of wastewater containing $20 \mathrm{ppm}$ of $\mathrm{MBO}$ and $10 \mathrm{mg}$ of $\mathrm{ZnO} / \mathrm{HAP}$ Nps with the initial $\mathrm{pH}$ of 4 was prepared and kept in the darkness for $30 \mathrm{~min}$. Afterward, the prepared mixture was exposed to UV irradiation using UV lamps under 
Fig. 1 Physical state and structure of 2-mercaptobenzoxazole (MBO), $\lambda_{\max }=294 \mathrm{~nm}$, molecule weight $\left(M w=151.19 \mathrm{gmol}^{-1}\right)$
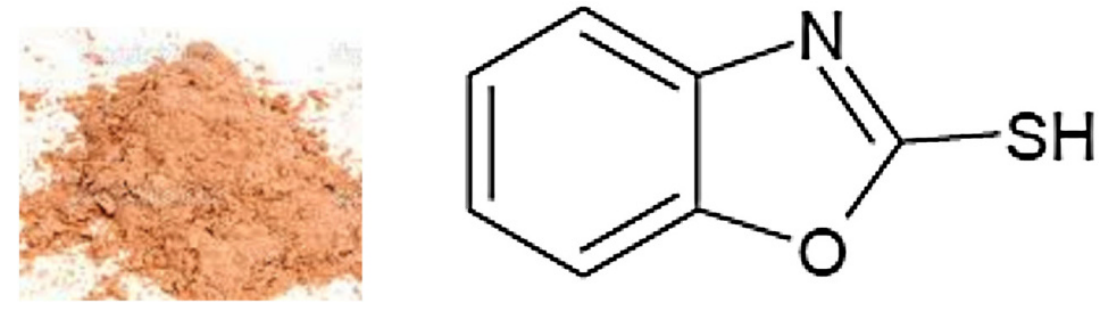

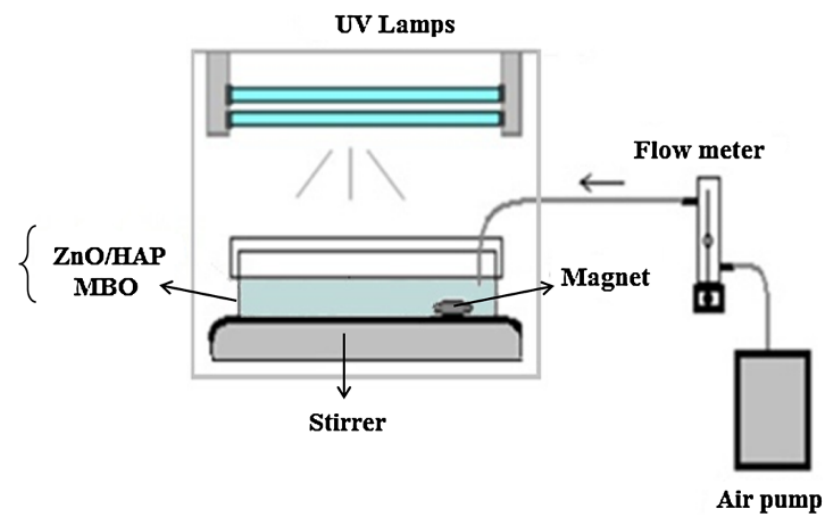

Fig. 2 Schematic representation of the UV photoreactor equipments

continuous stirring $(500 \mathrm{rpm})$ at room temperature $\left(25^{\circ} \mathrm{C}\right)$. The engaged UV lamps were two $8 \mathrm{~W}$ low-pressure mercury lamps (Philips, $\lambda=365 \mathrm{~nm}$ ) which were placed $5 \mathrm{~cm}$ above a jar containing the polluted water. All photodegradation experiments were conducted in a batch reactor. After illumination for different times $(8$ samples, see Fig. 7), the suspension is sampled and the degradation process of $\mathrm{MBO}$ is monitored by UV/Vis absorbance. To ensure repeatability, three trials of degradation of MBO were done for each experiment. According to the change in the concentration of MBO, The removal percentage $(\% R)$ of $\mathrm{MBO}$ versus time is defined as Eq. 1:

$\% \mathrm{R}=\left(\frac{\mathrm{C}_{0}-\mathrm{C}_{\mathrm{t}}}{\mathrm{C}_{0}}\right) \times 100$

where $C_{\mathrm{o}}$ is the initial concentration of $\mathrm{MBO}, C_{t}$ is the concentration of $\mathrm{MBO}$ at certain reaction time $t(\mathrm{~min})$.

\section{Results and discussion}

Characterization of $\mathrm{ZnO} / \mathrm{HAP}$ nanocomposite

\section{FTIR analysis}

FTIR spectroscopy is useful technique to prove formation of the $\mathrm{ZnO} / \mathrm{HAP} \mathrm{Nps}$. Analysis of $\mathrm{ZnO} / \mathrm{HAP}$ by FTIR demonstrated that all characteristic bands of $\mathrm{ZnO}$ and HAP appeared in the IR spectrum. For example, characteristic peaks of $\mathrm{O}-\mathrm{H}$ bending at $23,600 \mathrm{~cm}^{-1}, \mathrm{O}-\mathrm{H}$ stretching at
3,386 and stretching mode of $\mathrm{PO}_{4}^{-3}$ groups at 1,050 and $1,348 \mathrm{~cm}^{-1}$ (Amer et al. 2014). Moreover, the new band at $570 \mathrm{~cm}^{-1}$ could be attributed to the adsorption peak of $\mathrm{ZnO}$ species in $\mathrm{ZnO} / \mathrm{HAP}$ nanocomposite (Fig. 3) (Zhang et al. 2011).

$X R D$

XRD patterns of $\mathrm{ZnO} / \mathrm{HAP}$ nanocomposite revealed principal components of $\mathrm{HAP}$ and $\mathrm{ZnO}$ (Fig. 4a). According to the XRD pattern no impurities could be found in the particles confirming that the product was exclusively $\mathrm{ZnO} / \mathrm{HAP}$ composite. The crystallinity of the HAP was confirmed by the reflections observed at typical $2 \theta$ values of $25.87^{\circ}, 31.76^{\circ}, 39.8^{\circ}, 46.6^{\circ}$ and $49.5^{\circ}$ (JCPDS cards No. 74-565) (Zhao et al. 2014a). Meanwhile, the main peaks at $36.60^{\circ}(101), 47.65^{\circ}$ (102) and 62.70 (103) were attributed to hexagonal structure of ZnO Nps (JCPDS cards No. 89-0510). The particles diameter is determined from the diffraction peak broadening using Scherrer's equation (Birks and Friedman 2004):

$D=K \lambda / \operatorname{COS} \theta$

where $D$ is the crystal size of the Nps, the value of the coefficient $K$ is $0.90, \theta$ (radian) is the diffraction angle, $\lambda$ is the X-ray wavelength (1.5405 $\AA$ ), and $\beta$ is the width of XRD peak at half height. The average crystallite size of $\mathrm{ZnO}$ and HAP according to the most intensive diffraction peak at $2 \theta=25.87^{\circ}$ and $2 \theta=36.60^{\circ}$ are $12 \pm 1.2$ and $20 \pm 1.2 \mathrm{~nm}$, respectively (Fig. 2). These results were consistent with the IR observations (Fig. 3)

\section{TEM analysis}

TEM image clearly indicated that the synthesized $\mathrm{ZnO} /$ HAP Nps appeared rather monodisperse and have an average size of about $25 \mathrm{~nm}$ in diameter. Moreover, it consists of less agglomeration of spherical particles, confirming the formation of nanocomposite which is important for further advanced applications (Fig. 4b). Probably, HAP makes a shell layer around $\mathrm{ZnO}$ particles to avoid its growth and retains a stable dispersion compared to those without any protection (Giannakopoulou et al. 2012). 
Fig. 3 FTIR spectrum of prepared $\mathrm{ZnO} / \mathrm{HAP}$ nanocomposite

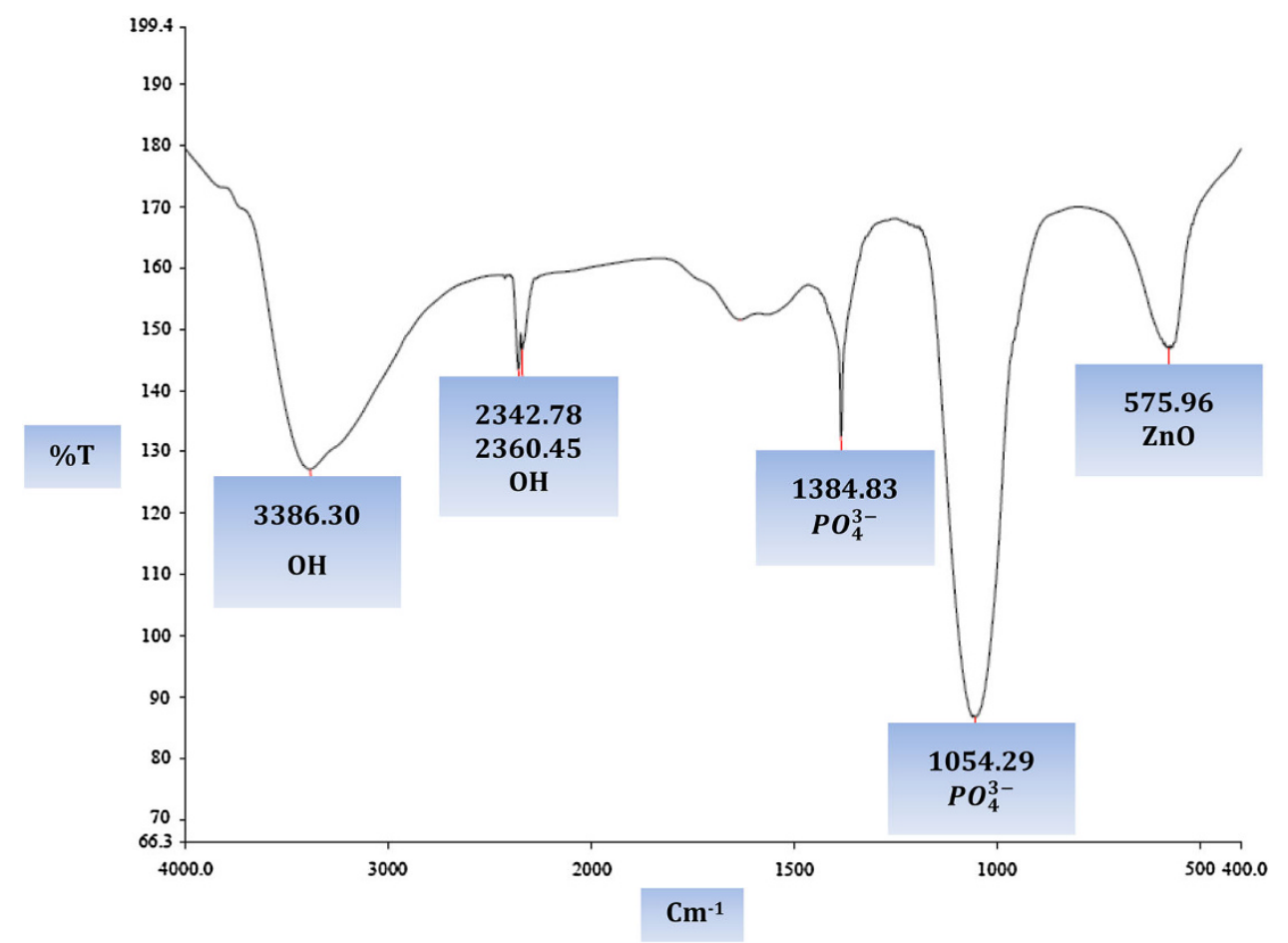

\section{BET analysis}

According to BET results, $\mathrm{ZnO} / \mathrm{HAP}$ nanostructure demonstrated the isotherm of type IV, with a hysteresis loop at relative pressure $\left(P / P_{\circ}\right)$ between 0.4 and 1.0, showing the existence of mesoporous structures (Fig. 5) (Mohamed and Aazam 2013). Meanwhile, the calculated values for $\mathrm{ZnO} /$ HAP nanocomposite including BET specific surface area (SSA, $\left.182.36 \mathrm{mg}^{2} \mathrm{~g}^{-1}\right)$, total pore volume $\left(0.0329 \mathrm{~cm}^{3} \mathrm{~g}^{-1}\right)$ and mean pore diameter $(7.182 \mathrm{~nm})$ indicated that our nanocomposite has a much greater surface area than pure $\mathrm{ZnO}$ Nps $(31.2 \mathrm{~nm})$ (Table 1). These results confirmed TEM and XRD findings (Figs. 5, 4). Consequently, higher specific surface areas and porous structures of $\mathrm{ZnO} / \mathrm{HAP}$ nanophotocatalyst enhanced its photocatalytic performance toward organic $\mathrm{MBO}$ pollutant rather than pure $\mathrm{ZnO} \mathrm{Nps}$ (Tables 1, 2) (Giannakopoulou et al. 2012). Moreover, SSA of $\mathrm{ZnO} / \mathrm{HAP}$ was greater than other reported catalysts in literature (Sakthivel et al. 2003), indicating its higher photocatalytic activity.

\section{Effect of $\mathrm{pH}$}

The effect of solution $\mathrm{pH}$ on the photocatalytic performance of the $\mathrm{ZnO} / \mathrm{HAP}$ nanoadsorbent was detected in the initial $\mathrm{pH}$ range of 3-11. The degradation efficiency of MBO increased first and then decreased slightly with rising pH from 8 to 11 (Fig. 6a). The photocatalytic degradation of $\mathrm{MBO}$ reaches maximum at neutral $\mathrm{pH}=7$. The impact of $\mathrm{pH}$ on the adsorption capacity of the $\mathrm{ZnO} / \mathrm{HAP}$ can be explained on the basis of the point of zero charge of $\mathrm{ZnO}$ and proton concentration (Sakthivel et al. 2003). The point of zero charge of $\mathrm{ZnO}$ was reported as 9.0 (Neppolian et al. 1998). At alkaline condition ( $\mathrm{pH}>9$ ), with the decrease of number of protons in the solution there are not enough protons to trap photo-electrons, which could restrain the production of hydroxyl groups. Subsequently, the nanoadsorbent affinity toward MBO becomes weak gradually. In contrast, at lower $\mathrm{pH}<9$, electrostatic interactions between $\mathrm{MBO}$ anions and the positive catalyst surface lead to strong adsorption of the former on the $\mathrm{ZnO} / \mathrm{HAP}$ catalyst (Sakthivel et al. 2003).

\section{Design of experiments and statistical analysis}

A series of experiments were carried out to understand the effects of various operating parameters on the degradation of $\mathrm{MBO}$ and to find out the most influential parameters affecting the process. Based on the single factor study, three parameters-photocatalyst dose, initial concentration of $\mathrm{MBO}$ and $\mathrm{pH}$ - were found to influence the reaction most. The Box-Behnken design of experiment method, which has been used along with RSM for the optimization of various experimental processes, was used to design the experiments required for the optimization (Zhang et al. 2010). The ranges and levels of independent variables considered in the design are shown in Table 3. The experimental results were fitted to a quadratic polynomial model for three parameters represented by Eq. 1. 

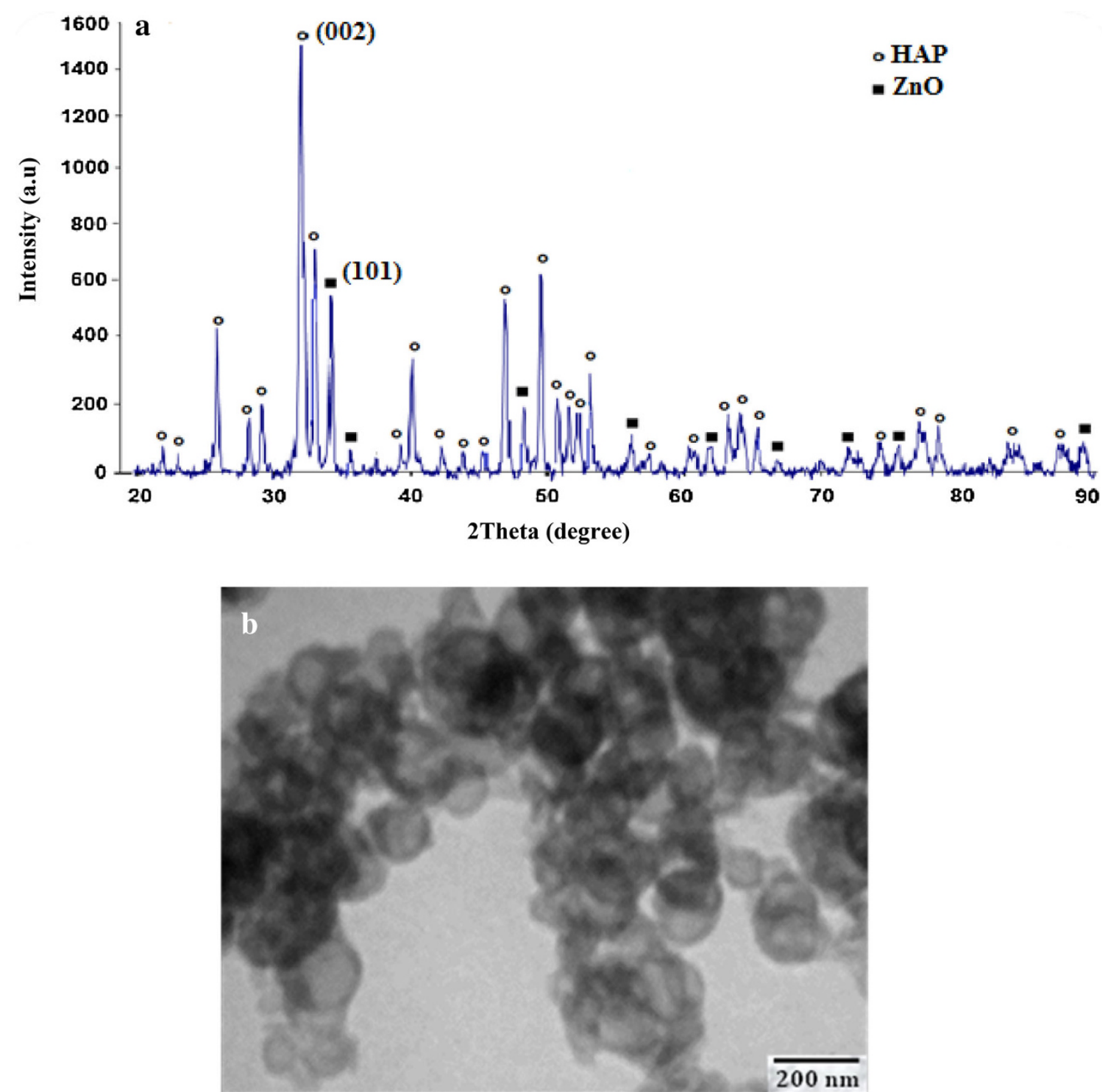

Fig. 4 a XRD pattern and b TEM micrograph of the ZnO/HAP nanocomposite recorded at 20,000 magnifications

$Y=\beta_{1} A+\beta_{2} B+\beta_{3} C+\beta_{11} A^{2}+\beta_{22} B^{2}+\beta_{33} C^{2}+\beta_{12} A B$ $+\beta_{23} B C+\beta_{31} C A$

where, $Y$ represents the response variable, $\beta_{1}, \beta_{2}, \beta_{3}$ the coefficients of the independent variables, $\beta_{11}, \beta_{22}, \beta_{33}$ quadratic coefficients, $\beta_{12}, \beta_{23}, \beta_{31}$ interaction coefficients and $A, B, C$ are the independent variables studied.

The predicted values of $\%$ were obtained by substituting the values of the parameters considered from Table 4 into Eq. 2.

$$
\begin{aligned}
Y_{1}= & 92.6+0.37 A-13.26 B+3.44 C+0.22 A B-0.1 A C \\
& +1.72 B C-3.74 A^{2}-3.04 B^{2}-4.27 C^{2}
\end{aligned}
$$

The designed experiments along with experimental and predicted values of the two responses are shown in Table 4.
The actual and the predicated values of degradation are in agreement with each other. Moreover, It is found that at $\mathrm{pH}=7$, the highest amount of $\mathrm{MBO}(\sim 90.50)$ is photodegraded by $\mathrm{ZnO} / \mathrm{HPA}$ nanophotocatalyst. These results further are consistent with Fig. $6 \mathrm{~b}$ findings.

\section{Effect of $\mathrm{ZnO} / \mathrm{HAP}$ loading}

To obtain the optimum dosage of $\mathrm{ZnO} / \mathrm{HAP}$, a series of experiments were carried using various amounts of nanophotocatalyst, from 10 to $200 \mathrm{mg} \mathrm{L}^{-1}$, in the solution of $\mathrm{MBO}$ (Fig. 6b). The results demonstrated that the rate of photodestruction of MBO increase linearly with $\mathrm{ZnO} / \mathrm{HAP}$ loading up to $50 \mathrm{mg} \mathrm{L}^{-1}$. This is attributed to the high number of active sites on photocatalyst surface which in 

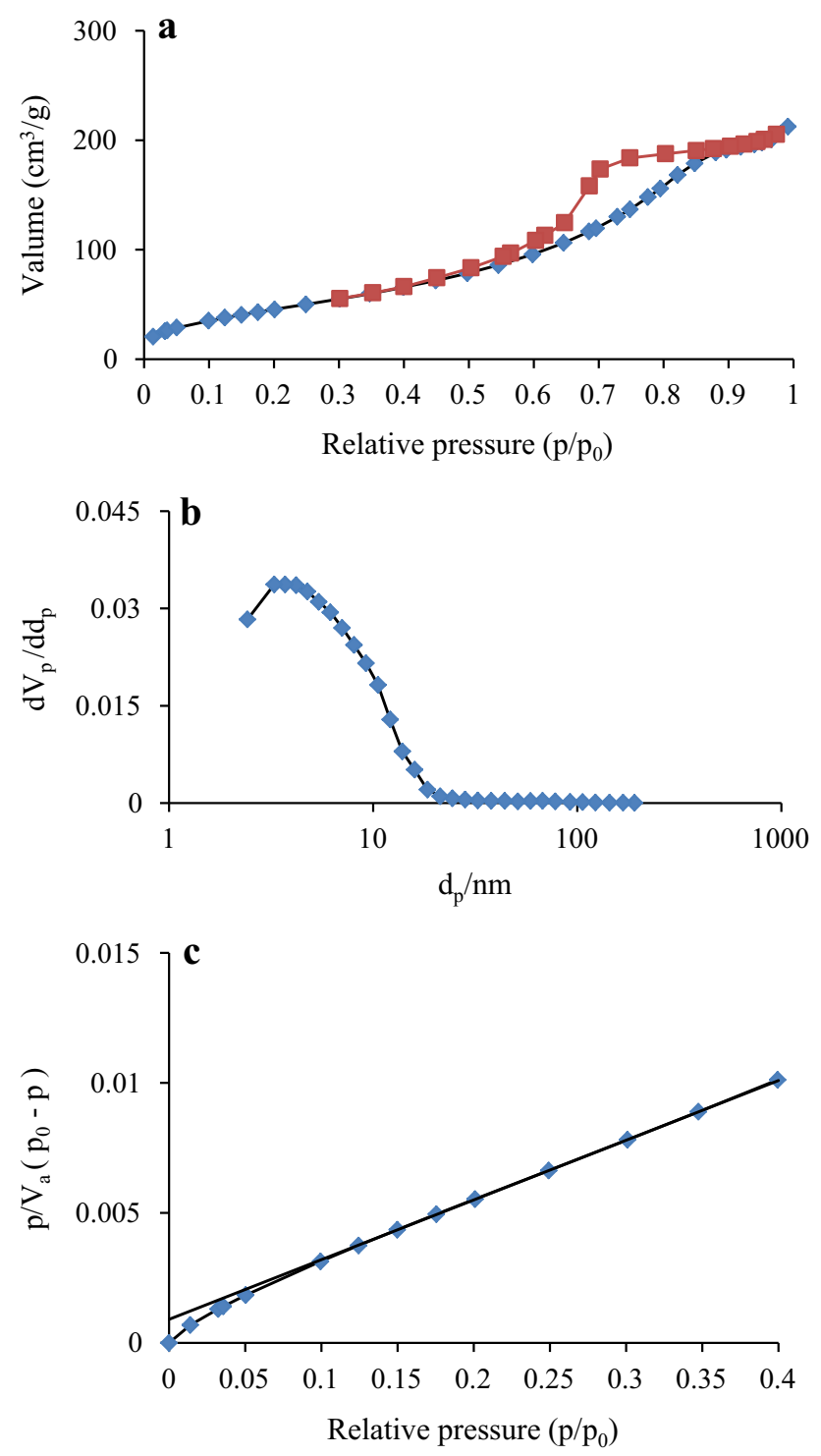

Fig. 5 a $\mathrm{N}_{2}$ adsorption-desorption isotherm, b pore size distribution curves, and $\mathbf{c}$ BET plot of $\mathrm{ZnO} / \mathrm{HAP}$ nanocomposite

Table 1 BET surface characteristics of the $\mathrm{ZnO} / \mathrm{HAP}$ and pure $\mathrm{ZnO}$ nanoparticles

\begin{tabular}{lllcl}
\hline Nanoadsorbent & $\begin{array}{l}\mathrm{BET} \\
\left(\mathrm{mg}^{2} \mathrm{~g}^{-1}\right)\end{array}$ & $\begin{array}{l}\text { Pore volume } \\
\left(\mathrm{cm}^{3} \mathrm{~g}^{-1}\right)\end{array}$ & $\begin{array}{l}\text { Pore size } \\
(\mathrm{nm})\end{array}$ & Reference \\
\hline $\mathrm{ZnO} / \mathrm{HAP}$ & 182.36 & 0.0329 & 7.182 & This work \\
Pure $\mathrm{ZnO}$ & 31.2 & 0.12 & 15.81 & $\begin{array}{c}\text { Georgekutty } \\
\text { et al. (2008) }\end{array}$ \\
\hline
\end{tabular}

turn increase the amount of hydroxyl and superoxide radicals (Bandekar et al. 2014). Above this loading, increase in turbidity of the solution reduces the UV light penetration throughout the solution (Hameed et al. 2011). Accordingly,
Table 2 Comparison of photocatalytic activity of nanoadsorbents on degradation rate of $\mathrm{MBO}$

\begin{tabular}{lll}
\hline Nanoadsorbent & Removal \% & Reference \\
\hline ZnO/HAP & 99.45 & This work \\
$\mathrm{ZnO}$ & 50.8 & This work \\
$\mathrm{HAP}$ & 41.8 & This work \\
\hline
\end{tabular}

degradation rate of $\mathrm{MBO}$ by nanocomposite would diminish. Therefore, an optimal dosage of $\mathrm{ZnO} / \mathrm{HAP}$ photocatalysts for the degradation of MBO was adjusted at $50 \mathrm{mg} \mathrm{L}^{-1}$.

\section{Effect of initial concentration of MBO}

In order to investigate the effect of initial concentration of $\mathrm{MBO}$ on the photocatalytic degradation efficiency of $\mathrm{ZnO} /$ $\mathrm{HAP}$, an experiment was carried out by varying the initial concentration of $\mathrm{MBO}$ from 10 to $100 \mathrm{mg} \mathrm{L}^{-1}$ at $\mathrm{pH}=7$ and room temperature $\left(25^{\circ} \mathrm{C}\right)$ (Fig. A1). The results depicted that the highest rate of degradation of $\mathrm{MBO}$ was achieved at the optimal initial concentration of $20 \mathrm{mg} \mathrm{L}^{-1}$. Beyond this value, the rate of degradation of MBO considerably decreases. It was assumed that at higher concentration, there are a fewer active sites on the nanoadsorbent surface, hence, the hydroxyl and oxygen radicals attacking the MBO molecules decrease with increase in concentration of MBO (Sakthivel et al. 2003). Moreover, the Figs. 6b, A1 results further were confirmed by correlation graph of removal of $\mathrm{MBO}$ and optimal ratio of catalyst loading/MBO (Fig. 7). Evidently there is good linear correlation between optimal ratio of catalyst loading/ MBO and removal efficiency of MBO pollutant. Approximately, at catalyst loading $/ \mathrm{MBO}=200$ the highest value of MBO is photo-eliminated. These results indicated that fewer values of both $\mathrm{ZnO} / \mathrm{HAP}$ nanocatalyst and $\mathrm{MBO}$ pollutant highly influence the removal efficiency of MBO in solution. These observations are in agreement with Figs. $6 \mathrm{~b}$ and $\mathrm{A} 1$ results.

Effect of irradiation time

Figure 8 represents the relationship between the removal of $\mathrm{MBO}$ with the irradiation time using $\mathrm{ZnO} / \mathrm{HAP}$ nanophotocatalyst. It was found that the rate of $\mathrm{MBO}$ degradation considerably increases with increase in irradiation time, so that the concentration of MBO was reduced to more than $85 \%$ within $2 \mathrm{~h}$. Apparently, with increase in irradiation time, the formation of strong $\mathrm{HO}^{\bullet}$ and $\mathrm{O}_{2}^{-2} \bullet$ radicals increases and thus by breaking different bonds in the MBO 
Fig. 6 a Effect of various solution $\mathrm{pH}$ and $\mathbf{b}$ effect of the $\mathrm{ZnO} / \mathrm{HAP}$ loading on the degradation of MBO (initial concentration: $20 \mathrm{mg} \mathrm{L}^{-1}$, irradiation time: $2 \mathrm{~h}$ and $25 \mathrm{~mL}$ solution of $\mathrm{MBO}$ )
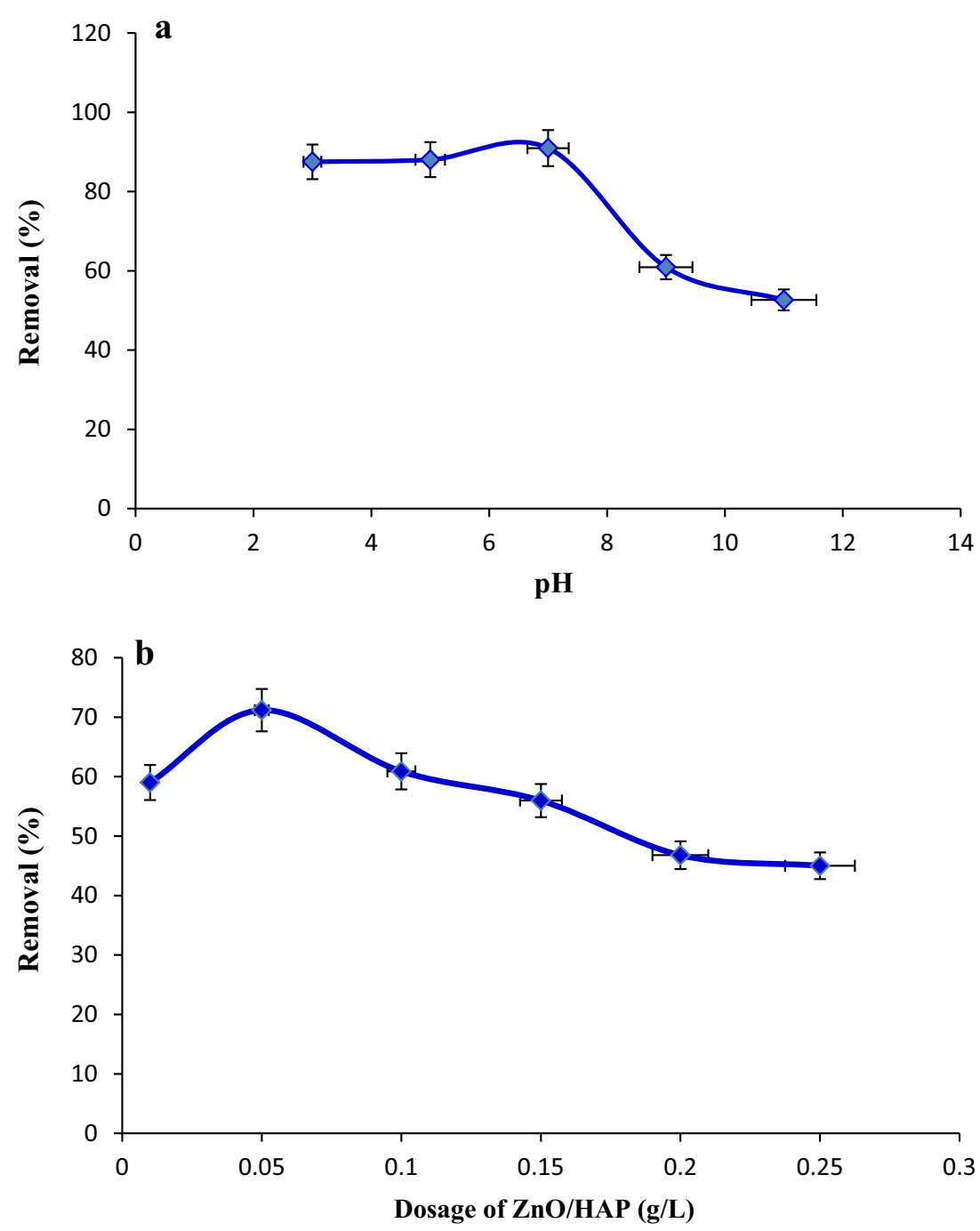

Table 3 The levels and ranges of variables in Box-Behnken statistical experiment design

\begin{tabular}{lllll}
\hline Independent variables & Symbol & \multicolumn{3}{l}{ Coded variable level } \\
\cline { 3 - 5 } & & Low -1 & Center 0 & High +1 \\
\hline $\begin{array}{l}\text { Catalytic dose }\left(\mathrm{g} \mathrm{L}^{-1}\right) \\
\begin{array}{c}\text { Initial concentration } \\
\text { of MBO (ppm) }\end{array}\end{array}$ & $\mathrm{A}$ & 0.01 & 0.05 & 0.1 \\
$\mathrm{pH}$ & $\mathrm{B}$ & 10 & 20 & 40 \\
\hline
\end{tabular}

molecule, lead to its full degradation in the course of time (Elmolla and Chaudhuri 2010; Hayat et al. 2011; Tian et al. 2012).

Effect of initial concentration of $\mathrm{MBO}$ on absorption capacity of $\mathrm{ZnO} / \mathrm{HAP}$

The absorption capacity of adsorbent was determined under optimized conditions $(\mathrm{pH}=7$, irradiation time $=120 \mathrm{~min}$, stirring speed $=400 \mathrm{rpm}$ ) by batch method (Parham et al. 2012). $50 \mathrm{mg}$ of $\mathrm{ZnO} / \mathrm{HAP}$ nanophotocatalyst was added to a $25-\mathrm{mL}$ solution containing $20 \mathrm{mg} \mathrm{L}^{-1}$ of $\mathrm{MBO}$ and stirred for $1 \mathrm{~h}$. Removal percent and adsorbed amount of MBO was probed by cold vapor atomic absorption measurement of the sample solution before and after removing process. The adsorption capacity of $\mathrm{ZnO} / \mathrm{HAP}$ was calculated using the following equation:

$q_{e}=\frac{\left(c_{0}-c_{t}\right) V}{M}$

where $q_{\mathrm{e}}$ is the amount of MBO adsorbed on the $\mathrm{ZnO} / \mathrm{HAP}$ $\left(\mathrm{mg} \mathrm{g}^{-1}\right), C_{0}$ and $C_{t}$ are concentration of $\mathrm{MBO}$ in solution before and after adsorption $\left(\mathrm{mg} \mathrm{L}^{-1}\right), V$ is the volume (L) and $M$ is the amount of the $\mathrm{ZnO} / \mathrm{HAP}$ used in the reaction. The loading capacity of nanocomposite was determined to be about $198 \mathrm{mg} \mathrm{g}^{-1}$. It was found that with increasing concentration of $\mathrm{MBO}$, the absorption rate is increased accordingly (Fig. A2). 
Table 4 Box-Behnken experiments along with actual and predicted values of responses

\begin{tabular}{llllll}
\hline MBO removal (\%) & & & & \\
\hline Run & $\begin{array}{l}\text { Catalytic dose } \\
\left(\mathrm{g} \mathrm{L}^{-1}\right)\end{array}$ & $\begin{array}{l}\text { Initial concentration } \\
\text { of MBO }(\mathrm{ppm})\end{array}$ & $\mathrm{pH}$ & Actual & Predicted \\
\hline 1 & 0.01 & 10 & 7 & 85.20 & 85.92 \\
2 & 0.1 & 10 & 7 & 85.36 & 85.22 \\
3 & 0.01 & 40 & 7 & 71.83 & 71.97 \\
4 & 0.1 & 40 & 7 & 72.87 & 73.15 \\
5 & 0.01 & 20 & 5 & 80.45 & 80.68 \\
6 & 0.1 & 20 & 5 & 81.52 & 81.62 \\
7 & 0.01 & 20 & 9 & 83.85 & 87.76 \\
8 & 0.1 & 20 & 9 & 83.52 & 88.29 \\
9 & 0.05 & 10 & 5 & 79.78 & 76.83 \\
10 & 0.05 & 40 & 5 & 79.25 & 66.88 \\
11 & 0.05 & 10 & 9 & 69.89 & 70.00 \\
12 & 0.05 & 40 & 9 & 57.24 & 57.19 \\
13 & 0.05 & 20 & 7 & 90.53 & 90.60 \\
14 & 0.05 & 20 & 7 & 90.82 & 90.60 \\
15 & 0.05 & 20 & 7 & 90.44 & 90.60 \\
\hline
\end{tabular}

Photocatalytic mechanism

Figure 9 elucidates the mechanism of photocatalytic oxidation of $\mathrm{MBO}$ using $\mathrm{ZnO} / \mathrm{HAP}$ nanophotocatalyst. After immobilizing ZnO Nps on the surface of HAP, the latter, being major contributor to the photodegradation of MBO. On the other hand, after modifying $\mathrm{ZnO}$ by HAP, the SSA and the concentration of hydroxyl groups considerably increase. In a typical photocatalytic reaction, photogenerating electrons and holes are captured by $\mathrm{O}_{2}$ and $\mathrm{H}_{2} \mathrm{O}$ absorbed by $\mathrm{ZnO}$ forming superactive ${ }^{\circ} \mathrm{OH}$ and $\mathrm{O}_{2}^{--}$oxidants. Hence, the enhanced photodegradation of MBO can be promoted by the increase in the concentration of surface hydroxyl groups and molecular oxygen. Accordingly, the increase in amount of hydroxyl not only increases the trapping sites for photogenerated holes, but also can increase the trapping sites for photogenerated electrons by adsorbing more molecular oxygen, resulting in more hydroxyl radicals to participate in the photocatalytic reaction. Consequently, $\mathrm{ZnO} / \mathrm{HAP}$ exhibited the highest photocatalytic activity than all the other reported nanophotocatalysts (Fig. 9) (Mohamed and Aazam; Sakthivel et al. 2003).

Comparison of photocatalytic activity of $\mathrm{ZnO} / \mathrm{HAP}$ with $\mathrm{ZnO}$ and HAP nanoparticles

In order to evaluate the efficiency of $\mathrm{ZnO} / \mathrm{HAP}$ nanophotocatalyst, identical experiments were also carried out with $\mathrm{ZnO}$, and HAP nanoparticles on the photocatalytic degradation of MBO and the results were illustrated in Table 2. Evidently, the results indicated that the highest removal efficiency of $\mathrm{MBO}(99.45 \%)$ occurred by $\mathrm{ZnO} /$ HAP using UV light as energy source. The trend of photocatalytic activity of our studied nanophotocatalysts for degradation of $\mathrm{MBO}$ was $\mathrm{ZnO} / \mathrm{HAP}>\mathrm{ZnO}>\mathrm{HAP}$ (Table 2). Obviously, doping $\mathrm{ZnO}$ in HAP matrix was expected to enhance the surface area, hydroxyl radicals species and improve photocatalytic performance of $\mathrm{ZnO} /$ HAP rather than pure $\mathrm{ZnO}$ and HAP Nps (see Table 1) (Giannakopoulou et al. 2012; Sakthivel et al. 2003).
Fig. 7 The correlation between photodegradation of $\mathrm{MBO}$ and optimal ratio of $\mathrm{ZnO} / \mathrm{HAP}$ loading and the initial MBO concentration

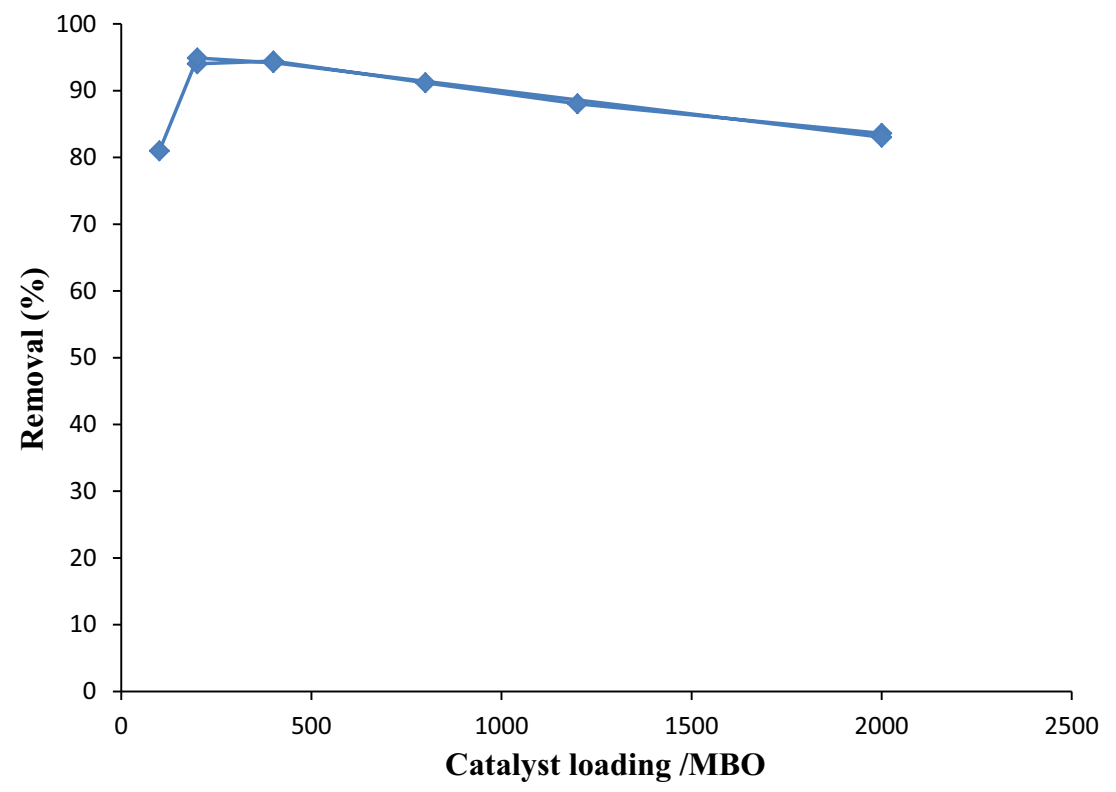



on degradation of $\mathrm{MBO}$ using $\mathrm{ZnO} / \mathrm{HAP}$ (initial concentration: $20 \mathrm{mg} \mathrm{L}^{-1}, \mathrm{pH} 7$, and $25 \mathrm{~mL}$ solution of $\mathrm{MBO}$ )

Fig. 9 Proposed photocatalytic mechanism of $\mathrm{MBO}$ by $\mathrm{ZnO} /$ HAP nanocomposite
Fig. 8 Effect of irradiation time
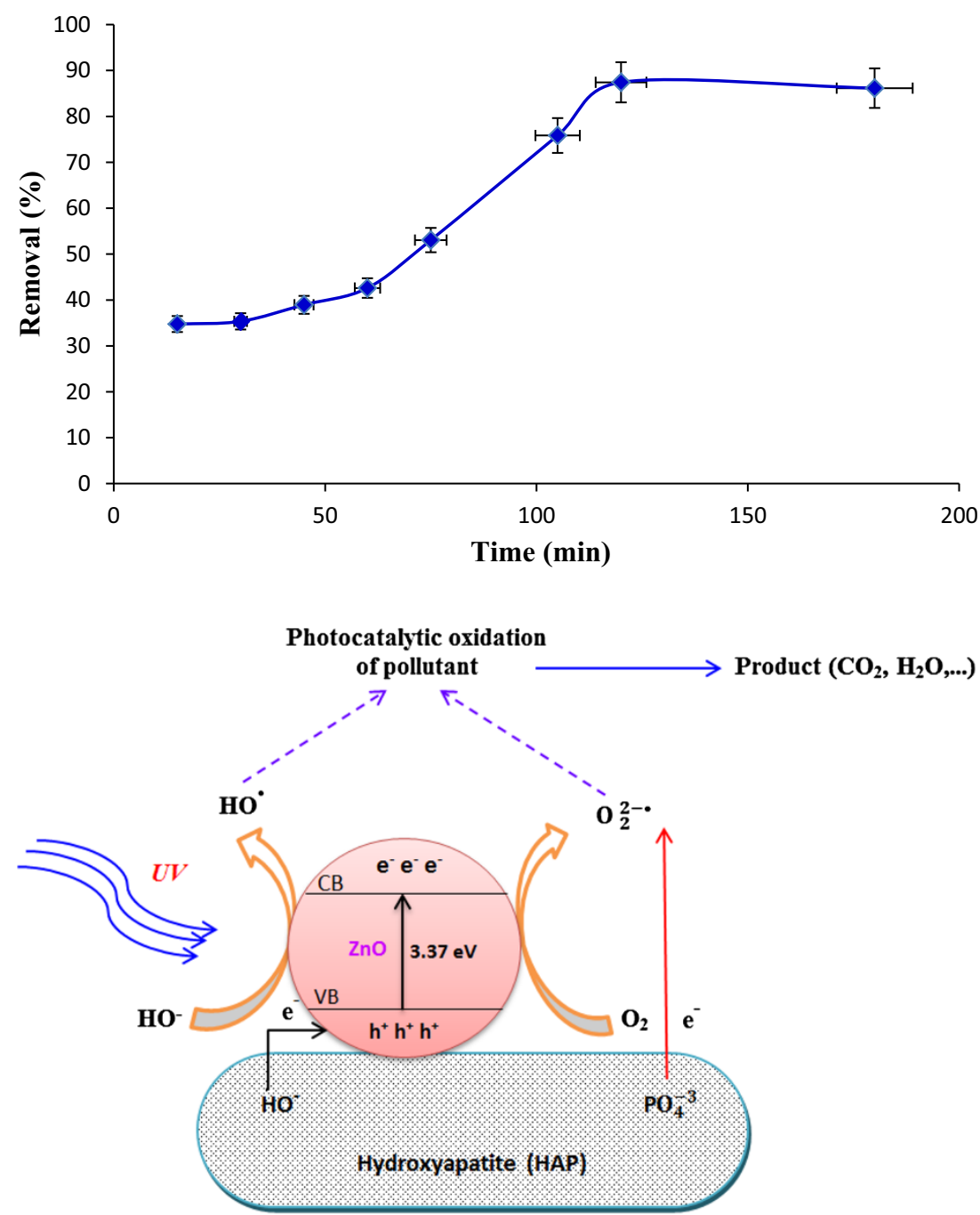

\section{Conclusions}

Conflict of interest The authors declare that they have no conflict of interest.

Open Access This article is distributed under the terms of the Creative Commons Attribution License which permits any use, distribution, and reproduction in any medium, provided the original author(s) and the source are credited.

\section{References}

Ali I (2012) New generation adsorbents for water treatment. Chem Rev 112:5073-5091

Allaouia AMM, Wong-Wah-Chung P (2010) Homogeneous photodegradation study of 2-mercaptobenzothiazole photocatalysed by sodium decatungstate salts: kinetics and mechanistic pathways. J Photochem Photobiol A Chem 212:153-160

Amer W et al (2014) Microwave-assisted synthesis of mesoporous nano-hydroxyapatite using surfactant templates. CrystEngComm 16:543-549

Antonopoulou M, Evgenidou E, Lambropoulou D, Konstantinou I (2014) A review on advanced oxidation processes for the 
removal of taste and odor compounds from aqueous media. Water Res 53:215-234

Azzaoui K et al (2014) Synthesis and characterization of composite based on cellulose acetate and hydroxyapatite application to the absorption of harmful substances. Carbohydr Polym 111:41-46

Bahnemann DW (1991) Mechanisms of organic transformations on semiconductor particles. Photochemical conversion and storage of solar energy. Kluwer Academic Publishers, The Netherlands

Bai X, Wang L, Zong R, Lv Y, Sun Y, Zhu Y (2013) Performance enhancement of $\mathrm{ZnO}$ photocatalyst via synergic effect of surface oxygen defect and graphene hybridization. Langmuir 29:3097-3105

Bandekar G, Rajurkar N, Mulla I, Mulik U, Amalnerkar D, Adhyapak P (2014) Synthesis, characterization and photocatalytic activity of PVP stabilized $\mathrm{ZnO}$ and modified $\mathrm{ZnO}$ nanostructures. Appl Nanosci 4:199-208

Birks L, Friedman H (2004) Particle size determination from X-ray line broadening. J Appl Phys 17:687-692

Bouyarmane H, Saoiabi S, Laghzizil A, Saoiabi A, Rami A, El Karbane M (2013) Natural phosphate and its derivative porous hydroxyapatite for the removal of toxic organic chemicals. Desalin Water Treat 1-5. doi:10.1080/19443994.2013.831797

Buazar F, Cheshmehkani A, Kassaee M (2012) Nanosteel synthesis via arc discharge: media and current effects. J Iran Chem Soc 9:151-156

Chong MN, Jin B, Chow CW, Saint C (2010) Recent developments in photocatalytic water treatment technology: a review. Water Res 44:2997-3027

Deng Z, Chen M, Gu G, Wu L (2008) A facile method to fabricate $\mathrm{ZnO}$ hollow spheres and their photocatalytic property. J Phys Chem B 112:16-22

Elmolla ES, Chaudhuri M (2010) Degradation of amoxicillin, ampicillin and cloxacillin antibiotics in aqueous solution by the UV/ZnO photocatalytic process. J Hazard Mater 173:445-449

Georgekutty R, Seery MK, Pillai SC (2008) A highly efficient Ag$\mathrm{ZnO}$ photocatalyst: synthesis, properties, and mechanism. J Phys Chem C 112:13563-13570

Giannakopoulou T, Todorova N, Romanos G, Vaimakis T, Dillert R, Bahnemann D, Trapalis C (2012) Composite hydroxyapatite/ $\mathrm{TiO}_{2}$ materials for photocatalytic oxidation of $\mathrm{NO}_{\mathrm{x}}$. Mater Sci Eng B 177:1046-1052

Greyson JC (1990) Carbon, nitrogen, and sulfur pollutants and their determination in air and water. CRC Press, USA

Habibi MH, Sheibani R (2010) Photocatalytic oxidation of four model mercaptans from aquatic environment using $\mathrm{Ag}-\mathrm{ZnO}$ nanocomposite thin film for odor control. J Adv Oxid Technol 13:192-199

Habibi MH, Sheibani R (2012) Removal of 2-mercaptobenzoxazole from water as model of odorous mercaptan compounds by a heterogenous photocatalytic process using $\mathrm{Ag}-\mathrm{ZnO}$ nanocomposite coated thin film on glass plate. Bull Environ Contam Toxicol 85:589-592

Hameed B, Akpan U, Wee KP (2011) Photocatalytic degradation of acid red 1 dye using $\mathrm{ZnO}$ catalyst in the presence and absence of silver. Desalin Water Treat 27:204-209

Hariharan C (2006) Photocatalytic degradation of organic contaminants in water by $\mathrm{ZnO}$ nanoparticles: revisited. Appl Catal A 304:55-61

Hayat K, Gondal M, Khaled MM, Ahmed S, Shemsi AM (2011) Nano $\mathrm{ZnO}$ synthesis by modified sol gel method and its application in heterogeneous photocatalytic removal of phenol from water. Appl Catal A 393:122-129

Hokkanen S, Repo E, Westholm LJ, Lou S, Sainio T, Sillanpää M (2014) Adsorption of $\mathrm{Ni}^{2+}, \mathrm{Cd}^{2+}, \mathrm{PO}_{4}{ }^{3-}$ and $\mathrm{NO}_{3}{ }^{-}$from aqueous solutions by nanostructured microfibrillated cellulose modified with carbonated hydroxyapatite. Chem Eng J 252:64-74

Kassaee M, Buazar F (2009) Al nanoparticles: impact of media and current on the arc fabrication. J Manuf Process 11:31-37

Kassaee M, Motamedi E, Majdi M, Cheshmehkani A, SoleimaniAmiri S, Buazar F (2008) Media effects on nanobrass arc fabrications. J Alloys Compd 453:229-232

Leh F, Chan K (1973) Sulfur compounds. Pollution, health effects, and biological function. J Chem Educ 50:246

Liu JX, Wang F, Shen JX, Lai QH, Gai Y (2013) Study of nanohydroxyapatite adsorption in heavy metals. Adv Mater Res 777:15-18

Mahdavi S, Jalali M, Afkhami A (2012) Removal of heavy metals from aqueous solutions using $\mathrm{Fe} 3 \mathrm{O} 4, \mathrm{ZnO}$, and $\mathrm{CuO}$ nanoparticles. J Nanopart Res 14:1-18

Mohamed R, Aazam E (2013) Synthesis and characterization of PtZnO-hydroxyapatite nanoparticles for photocatalytic degradation of benzene under visible light. Desalin Water Treat 51:6082-6090

Mohammad Vaseem AU, Yoon-Bong Hahn (2010) ZnO Nanoparticles: Growth, Properties, and Applications. In: Umar A (ed) Metal Oxide Nanostructures and Their Applications, vol 5. American Scientific Publishers, USA, pp 1-36

Neppolian B, Sakthivel S, Arabindoo B, Palanichamy M, Murugesan V (1998) Photocatalytic degradation of textile dye commonly used in cotton fabrics. Stud Surf Sci Catal 113:329-335

Parham H, Khoshnam F (2013) Highly efficient and simultaneous removal of 2-mercaptobenzothiazole and 2-mercaptobenzoxazole from water samples by copper oxide nanoparticles. J Chem Technol Biotechnol 88:1736-1743

Parham H, Zargar B, Shiralipour R (2012) Fast and efficient removal of mercury from water samples using magnetic iron oxide nanoparticles modified with 2-mercaptobenzothiazole. J Hazard Mater 205:94-100

Sakthivel S, Neppolian B, Shankar M, Arabindoo B, Palanichamy M, Murugesan V (2003) Solar photocatalytic degradation of azo dye: comparison of photocatalytic efficiency of $\mathrm{ZnO}$ and $\mathrm{TiO}_{2}$. Sol Energy Mater Sol Cells 77:65-82

Saravanan R, Karthikeyan S, Gupta V, Sekaran G, Narayanan V, Stephen A (2013) Enhanced photocatalytic activity of $\mathrm{ZnO} / \mathrm{CuO}$ nanocomposite for the degradation of textile dye on visible light illumination. Mater Sci Eng C 33:91-98

Sheela T, Nayaka YA, Viswanatha R, Basavanna S, Venkatesha $T$ (2012) Kinetics and thermodynamics studies on the adsorption of $\mathrm{Zn}$ (II), $\mathrm{Cd}$ (II) and $\mathrm{Hg}$ (II) from aqueous solution using zinc oxide nanoparticles. Powder Technol 217:163-170

Tian C, Zhang Q, Wu A, Jiang M, Liang Z, Jiang B, Fu H (2012) Cost-effective large-scale synthesis of $\mathrm{ZnO}$ photocatalyst with excellent performance for dye photodegradation Chem Commun 48:2858-2860

Wei W, Sun R, Jin Z, Cui J, Wei Z (2014) Hydroxyapatite-gelatin nanocomposite as a novel adsorbent for nitrobenzene removal from aqueous solution. Appl Surf Sci 292:1020-1029

Xie J et al (2013) Preparation of titania/hydroxyapatite $\left(\mathrm{TiO}_{2} / \mathrm{HAp}\right)$ composite photocatalyst with mosaic structure for degradation of pentachlorophenol. Mater Lett 110:57-60

Yusoff N, Ong S-A, Ho L-N, Wong Y-S, Khalik W (2014) Degradation of phenol through solar-photocatalytic treatment by zinc oxide in aqueous solution. Desalin Water Treat 1-8. doi:10.1080/19443994.2014.908414

Zhang J, Fu D, Xu Y, Liu C (2010) Optimization of parameters on photocatalytic degradation of chloramphenicol using $\mathrm{TiO}_{2}$ as photocatalyst by response surface methodology. J Environ Sci 22:1281-1289 
Zhang G, Shen X, Yang Y (2011) Facile synthesis of monodisperse porous $\mathrm{ZnO}$ spheres by a soluble starch-assisted method and their photocatalytic activity. J Phys Chem C 115:7145-7152

Zhao X-Y, Zhu Y-J, Lu B-Q, Chen F, Qi C, Zhao J, Wu J (2014a) Hydrothermal synthesis of hydroxyapatite nanorods using pyridoxal-5'-phosphate as a phosphorus source. Mater Res Bull 55:67-70
Zhao X-Y, Zhu Y-J, Zhao J, Lu B-Q, Chen F, Qi C, Wu J (2014b) Hydroxyapatite nanosheet-assembled microspheres: hemoglobin-templated synthesis and adsorption for heavy metal ions. J Colloid Interface Sci 416:11-18 